\title{
NUCLEAR TECHNICIAN MANPOWER IN THE WESTERN UNITED STATES
}

Development of a survey Population for

- A U. S. Atomic Energy Commission Study of Nuclear Technician Manpower supply and Demand in the Western Region

Strbmitted to:

Division of Labor Relations

U. S. Atomic Energy Commission

Preparea by:

Western Interstate Nuclear Board

P. 0. Box 15038

Iakẹwood, cólorado 80215

(303) 238-8383

under

Contract No. AT (11-1) -2330

Date: February 25, 1974

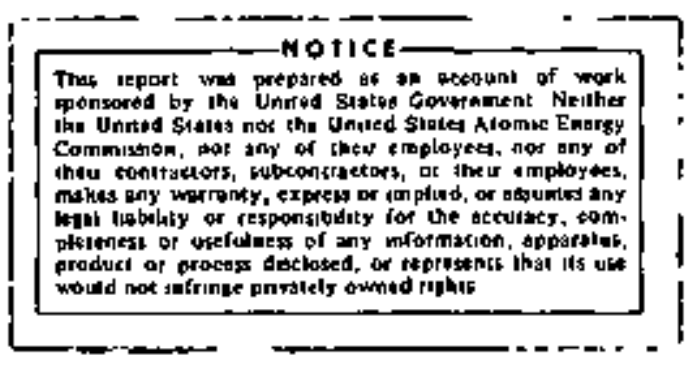




\section{DISCLAIMER}

This report was prepared as an account of work sponsored by an agency of the United States Government. Neither the United States Government nor any agency Thereot, nor any of their employees, makes any warranty, express or implied, or assumes any legal liability or responsibility for the accuracy, completeness, or usefulness of any information, apparatus, product, or process disclosed, or represents that its use would not infringe privately owned rights. Reference herein to any specific commercial product, process, or service by trade name, trademark, manufacturer, or otherwise does not necessarily constitute or imply its endorsement, recommendation, or favoring by the United States Government or any agency thereof. The views and opinions of authors expressed herein do not necessarlly state or reflect those of the United States Government or any agency thereof. 


\section{DISCLAIMER}

Portions of this document may be illegible in electronic image products. Images are produced from the best available original document. 


\section{Abstract}

This report describes the work performed by the western Interstate Nuclear Boaxd (WINB) under USAEC Contract No. AT (11-1) -2330 in developing a survey population for a nuclear technician supply and demand study being conducted by the U. S. Atomic Energy Commission in the Western. United states. WINB efforts in identifying actual and/or potential employers and sources of supply of nuclearrelated technicians and in preparing mailing lists for the USAEC study are discussed. 


\section{WINB Project steering committee}

Filliam R. Hendee, Ph.D.

Associate Professor of Radiology

University of Colorado Medical Center

James L. Montgomery

Health Physicist

Dccupational and Radiological Health Division

Colorado Department of Health

L. Paul Robertson, Ed.D.

Administrator

Continuing Education Programs

Sandia taboratories

Wyatt M. Rogers, Jr. (Project Dírector)

Associate Director

Western Interstate Nuclear Board

Alfred T. Whatley, Ph.D.

Executive Director

Western Interstate Nuclear Board

\section{AEC Project officer}

Larry L. Barker, Manpower Analyst

Manpower Information Systems Branch.

Division of Labor Relations

U. s. Atomic Energy Commission

\section{AEC Contract Administrator}

George MacPherson

Contracts Management office

Chicago Operations office

U. S. Atomic Energy Commission 


\section{Acknowledgements}

The Western Interstate Nuclear Board wishes to exprés its appreciation to the many individuals and organizations assisting in various ways during the conduct of this work. These include the numerous respondents to letters of inquiry, questionnaires, and telephone requests for information.

Special recognition for their assistance is given to the following individuals:

Alaska Jon Scribner, Alaska Environmental Conservation Department

Arizona Donald C, Gilbert, Arizona Atomic Energy Comission California Dr. Simon Kinsman, California Dept: of Public Health

Colorado James Montgomery and Robert Siek, Colorado Division Occupational and Radiological Health

Dr. William Hendee, University of Colorado Medical Center

Idaho Michael christie, Idaho Radiation control section

Montana Larry Lloyd, Montana Radiation Control Bureau

Nevada Billiam Horton, Nevada Radiation Control Section

New Mexico Edward Kaufman, state Environmental Improvement. A'gency

Dr. L. Paul Robertson, Sänaia Laboratories

Oregon Dr. Marshall parrott, Oregon Radiation Control Division

Utah Dennis Dalley, Utah Radiation Control section

Washington Arnold Moen and clifford Lewis, Washington Radiation control section

Wyoming Robert Sundin, Wyoming Environmental Protection Department 
1. Introduction

In view of the continuing growth of the nuclear ifidustry in the Western United States, the Western Interstate Nuclear Board has over the past three years explored with a number of different groups the desirability of determining the supply and demand for nucleas technician personnel and the adequacy of nuclear technician training programs in the WINB Region. Discussions with industry, medical, and educational organizations have indicated a need for more "supply and demand" information to facilitate long-range planning.

Similar surveys have been conducted in the 17-state Southern Region and in sections of the Midwest.* The American Nuclear Society and the USAEC have performed national surveys on certain segments of the nuclear industry (e.g., utility staffing for nuclear power plants); however, these nationwide studies have not provided information as to where the technicians are needed, which institutions are likely to supply such trained personnel, nor in the detail necessary for state-level or regional planning. Nor has such a regional survey been conducted in the Western area of the nation.

In an effort tó develop information on employment requirements and educational need's for nuclear technicians in the Western Region, the wINB submitted proposals to conduct joint $l_{Y}$ with the U. S. Atomic Energy Commission a "supply and dernand" survey for the Western united States. Subsequently, WINB was awarded USAEC Contract No. AT(11-1)2230 dațed May 15, 1973 ţo perform the initial phases of such a supply and demand survey.

\section{Purpose and Objectives:}

In undertaking the scope of work described below, the wINE sought to develop essential information toward the conduct of a Western regional survey by the USAEC of current employment, employment needs in the neax-term

* See Bibliography, references 4 and $B$. 
Euture, and sources of supply for nuclear technician occupations. Based on the survey population identified in this WINB project. USAEC is undertaking the regional survey utilizing questionnaires and a computerized data reduction system. USAEC plans to incorporate the Western region survey results into its newly-developed national information system for nuclear-related technician manpower.

3. Scope of Work

The tasks performed under this contract consisted of: (a) development of a population (or "universe") of actual or potential employers and sources of supply of nuclear and nuclear-related 'technicians in the twelve (12) member states* of the Western Interstate Nuclear Compact; and (b) preparation of mailing Iists and address labels for subsequent use by USAEC in conducting a supply-demand survey for nuclear technicians in the Western United States.

All identifiable technical occupations in the nuclear field (including radiologic health, medical arts, industry, and other segments of the field) requiring specialized formal or "on-the-Job" training beyond high school, but below the baccalaureate level were included. Also surveyed were nuclear-related occupations in "conventional" industries such as industrial radiographers and chemical plant operators who work with radioisotopes, process radiation, among others.

On the "supply" side, educational progrants for nuclear technicians affered by industry, hospitals, government agencies, and educational institutions throughout the wINB Region were identified as actual or potential sources of supply or training.

On the "demand" side, "all major segments of the nuclear energy industry, conventional industries involved in atomic energy activities, research facilities, medical

* Alaska, Arizona, California, Colorado, Idaho, Montana, Nevada, New Mexico, Oregon, Utah, Washington, and Wyoming. (Hawaii was solicited for participation, but did not respond.) 
clinics and institutions, government agencies, 'federal contractor organizations, and educational institutions which are employers or prospective employers were sought to be included in the population.

4. Development of the Survey Population: Methodology

a. Project Design and Planning

In designing the project plan, wINB drew extensively from the experiences of the Southern Interstate Nuclear. Board (SINB) in conducting a nuclear technician supply/: demand survey for the 17 Southern states in 1970-71. Expertise developed in the USAEC's nuclear manpower information program was drawn upon during the proposal pxeparation, planning, and implementation phases. Based upon these experiences and WINB's knowledge of the characteristics of the nuclear industry in the west. it was decided to employ the services of a steering committee to assist the WINB staff in developing its plans and contacts and in reviewing progress.

Because of their central role in regulating nuclear energy and the extensive information that they maintain, state radiation control agericies and USAEC regulatory offices were key sources of assistance. other educational, industry, and government sources were also contacted.

The flow chart (Figure 1) summarizes the sequence of activities, sources of information, and procedures used in developing the survey population.

b. 'Implementation

(1) Preliminary data from the states and the USAEC A primary source of preliminary data was the listings of licensees of radioactive materials. registrants for X-ray, radium, etc. provided by USAEC and state radiation. control agencies. These listings identified 2,953 radioactive materials licenses and 52,325 registrations for $\mathrm{X}$-ray and other radiation sources in the West. Table $A$ 
F1gure 1

Flow Chart - Development of Survey Population

Przmary sources "Pemand"

AEC I 2sentee

lists

\section{Agreament stain}

ligenset lists

\begin{tabular}{l} 
X-ray, other \\
"user" lists \\
from states \\
\hline Other employers: \\
Gov'm't, agenciea \\
Equational \\
Exivate industries \\
Medical \\
Other
\end{tabular}

'Supply'

Colleges, other

hrgher education

Vocat lorial

institutes

Haspital6,

Medical scheois

On-the-job

training
Initial grocessing

_. Strcondary

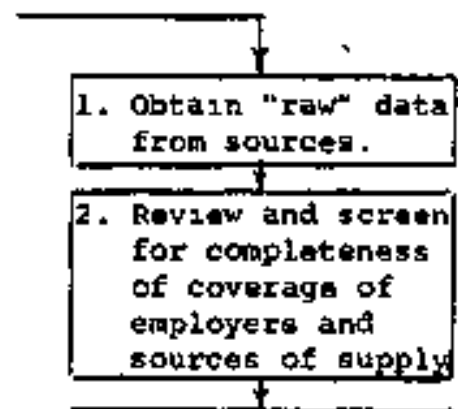

3. "Key contact"

information.

a. If not pro-

vided in 1ni-

tial 120ts ts

quent info.

via tuestion-

- Ta nase.

- b. If provided, add to master 12046.

'

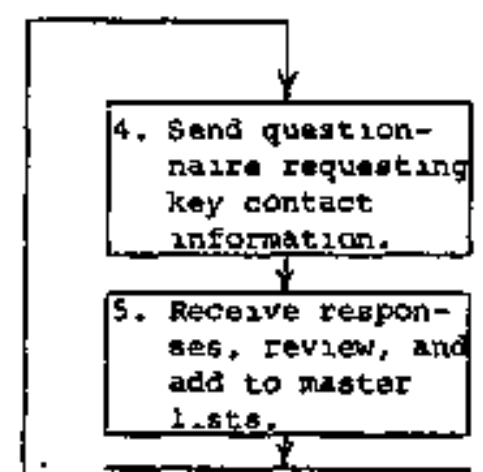

6. Telephone, other follow-up--Add new information to 125.t5.

rinal Procesting

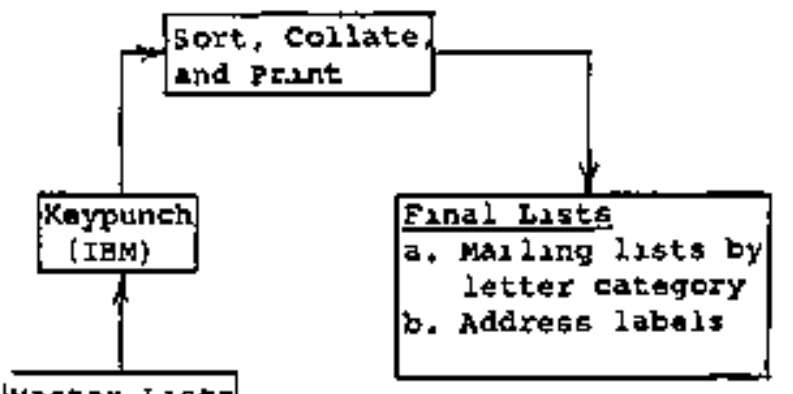

Master L1sts

Categorize

by letter

code.

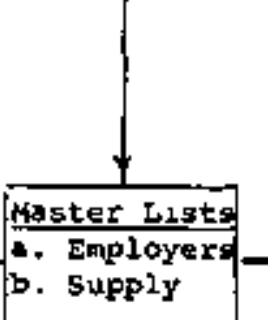


Table A

RADIOACTIVE MATERIALS AND RADIATION SOURCES

UNDER STATE AND FEDERAL REGULATION TN THE WINB REGTOR

\section{State}

Alaska

Arizona

california

Colorado

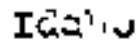

Montana.

Nevada

oregon

Utah

- Washington

Wyoming

WTrk Region

National Totals
New Mexico
Agreement State Radioactive
State

USAEC Mat'ls: Totals-State state X-ray, other Totals-All

Licenses* and Federal. Badiation Sources**

--2
203
1,290
240
95
--
61
--
152
--
248
---
2,289
0,733

\section{7}

14

184

47

1

56

12

109

18

111

34

51

664

8,013
27

217

1,474

287

96

56

73

109

170

111

282

51

2,953

16,746
Sources

3,054

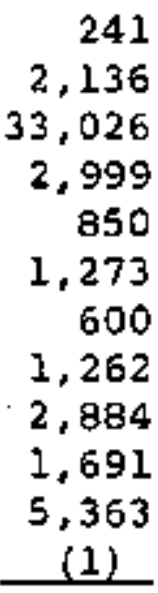

52,325

NA
* Data from U. S. Atomic Energy Comission as of December 31, 1972.

**Data from WINS survey of state radiation control programs as of January $1,1973$.

(1) Wyoming does not have mandatory registration program.

$\mathrm{NA}=$ Not available
268

2,353

34,500

3,286

946

1,329

673

1, 371

1,802

5,645

51

55,278

NA 
contains a state-by-state breakdown of this data. of course, the number of license holders and registrants was considerably less since many organizations possess more than one license or registration. Nevertheless, this provided an indication of the overall potential population to be identified.

It was recognized that USAEC and state regulatory data would not be comprehensive in coverage, since some organizations that. may employ or train nuclear technicians may not utilize radiation sources requiring state or federal licensure or registration. Thus it was necessary to utilize additional sources of information for đeveloping preliminary listings. The initial listing of categories of potential employers and supply sources for the population is as follows:

\section{Potentia1 Population by catecory}

\section{Employers}

(a) Licensees (medical, industrial, other) of radioactive materials (obtained from USAEC and "agreement state" agencies)

(b) Registrants for X-ray, radium, other nonagreement radioactive materials, and.other radiation bources (obtained from state agencies)

(c) Radiological health organizations, pubiic and private lobtained from U. S. Environmental Protection Agency, HEW Bureav of Radiological Health, AEC, state agencies, others)

(d) Private firms producing "N" stamp components, $x$-ray equipment, etc. but not necessarily requiring state and AEC licenses (obtained from American Society of Mechanical Engineers, American Nationai standards Institute. Nuclear News Buyers Guides, American Association for Advancement of Science's guide to scientific Instruments. AEC) 
(e) Eederal agencies (research, operations, regu-

: latory) (obtained from ARC)

(f) Reactor operations (utilities, universities, etc.) (obtained from AEc)

(g) AEC contractors including university and company-operated laboratories (obtained from AEC)

(h) other industrial (engineering, exploration, consulting, etc.)

Training organizations

(a) colleges and universities lobtain from state. educational agencies, educational assoi iations, National Center for Educational statistics.)

(b) vocational schools (state agencies)

(c) Hospitals, medical clinics, and medical schools (state agencies, medical societies)

(d) "On-the-job" training (obtain info. via AEC questionnaire)

Upon receipt and initial evaluation of listings from state agencies and USAEC, it became obvious that supplementary data was needed, particularly "key contact" information (names of individuals in the organizations to whor questionnaires and other communications are addressed). The steering comittee offered numerous suggestions and provided additional sources of contacts. Subsequently, state agencies were re-contacted to supply key contacts wherever possible. Additional listings providing this information were supplied by several states.

During sessions with the steering committee, it * was decided to eliminate from the population individual physicians, veterinarians, and others who typically employed only one or a few medical assistants not requiring special training in $x$-ray or nuclear technology. Usually, such physicians either perform $X$-ray procedures themselves or train their medical assistants to perform such procedures which comprise only a small fraction of their time. 
Thus, the population was naxxowed considerably and was linited to those organizations that enployed technicians requiring specialized training and whose. work responsibilities included a significant fraction of their time devoted to X-ray and/or other nuclear-or radiation-related procedures.

(2) Data from other Sources

Supplementary information on potential employers and sources of supply, not available in some cases from USAEC and the state agencies, was. obtained from such sources as American Nuclear Society's nuclear News Buyer's Guide, 1973; Companies Holding Certificates of Authorization for Use of code Symbol Stamps, 1971, and its 1972 supplement: Technician Yearbook, 1971-72; Educational Directory, 1972-3, by the National center for Educational statistics; "Official Roster of Affiliate Societies" * American society of Radiologic Technologists, and American Association for the Advancement of Science's, Guide to Scientific Instruments, 1971-72.

Organizations located in the festern Region were extracted from these supplementary sources and. were placed on the preliminary lists.

"Key contact" information

After review by the steering committee, it was determined that a brief questionnaire should be. sent to those organizations for which the wINB staff had not previously been able to identify key contacts. These totalled approximately 919. Figure 2 shows the self-adaressed, stamped card questionnaire; the letter of transmittal is shown in Figure 3.

Allowing a six-week period for returns of these questionnaires, the staff received approximately 335 replies plus 22 envelopes returned as "undeliverable" or due to incorrect address, etc. 
Fiqure 2

ORGATMZZATMONON

WINB-USAEC NUUCEEAR TECHNICIAN SURVEY.

AOORESS

CITY-STATE-Z̃F CODË

NAME OF KEY PERSON TO WORK WITH T̈HÄS PROAJËCT

TITLE

PHONE NO

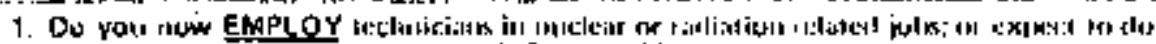

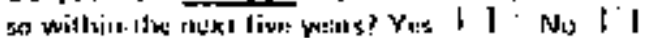

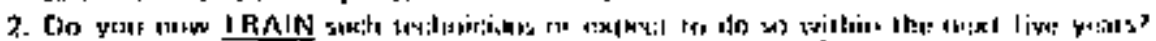
Yn: I : $N_{1}$, i I

PLEASE RETURN AS \$OQN AS PQSSHELE

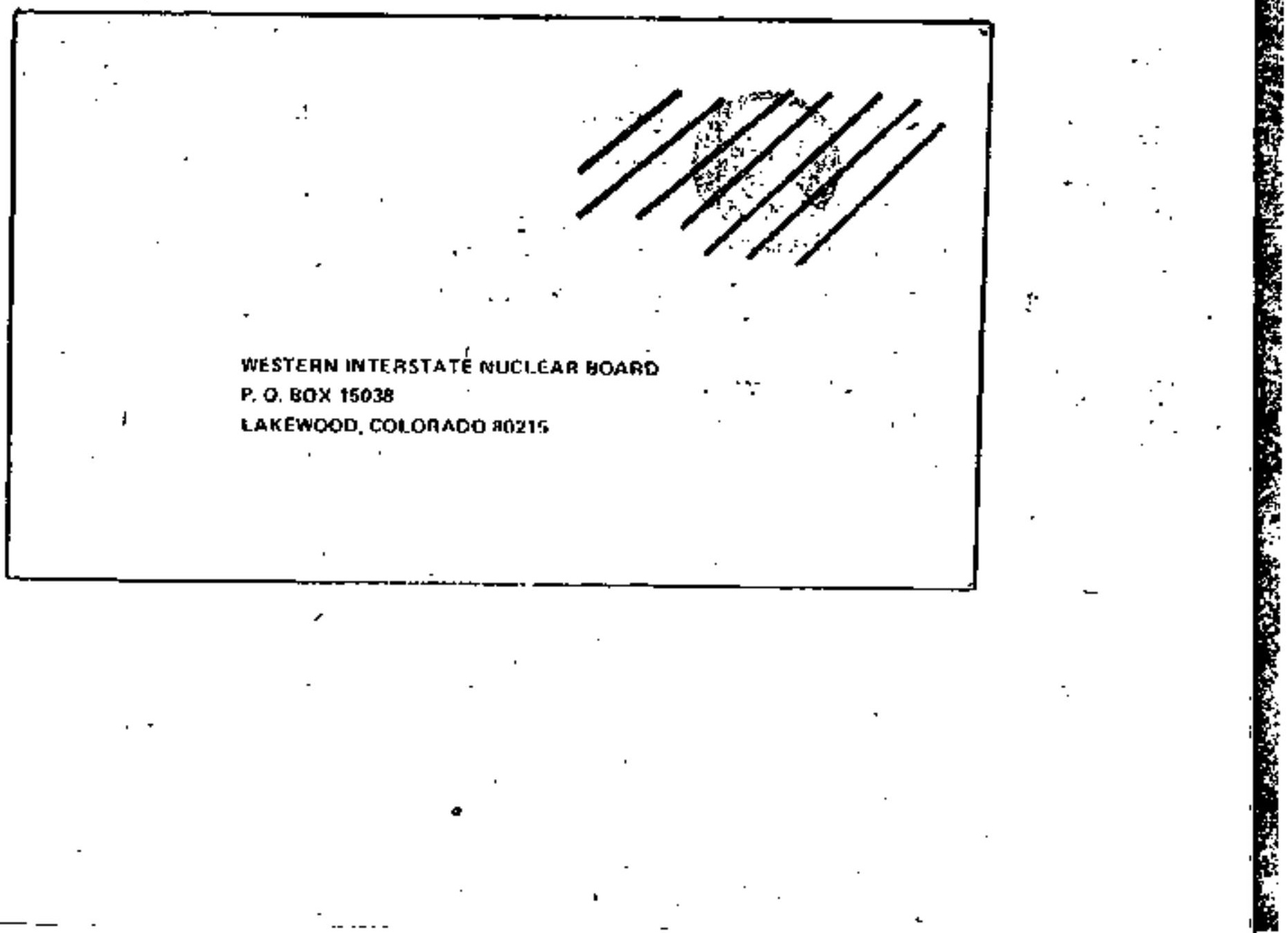




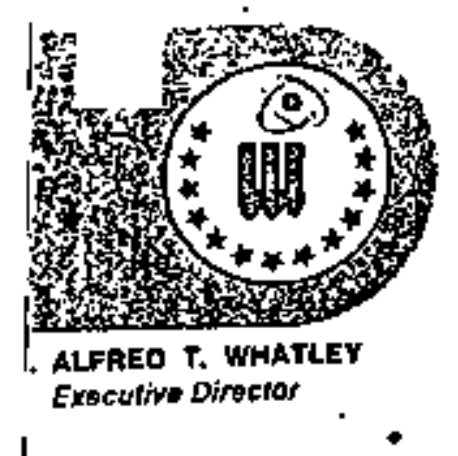

Gent lemen :
Figure 3

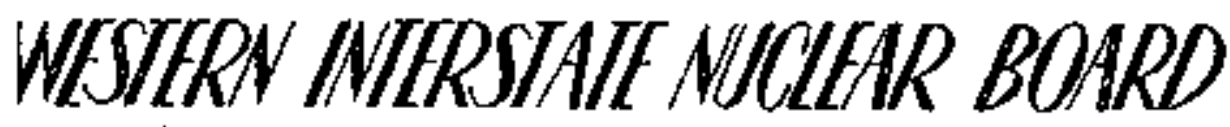

P.O, BOX 15038 - LAKEWOOO, COLORADO BO2t5 - 1303) 238'-8393

The western Interstate Nuclear Board (WINB) and the $\mathrm{U}$. S. Atomic Energy Commission are jointly conducting a survey of employment and educational programs for technicians in nuclear- and radiationrelated occupations in the 13-state Western Region served by wiNB. 'his regional survey will become a part of a national information system for nucleax-rolated manpower operated by USAEC with the copperation of the Bureau of Labor Statistics, National Science Foundation, and other agencies.

The objective of the survey and the information system is to supply data needed by individual firms, educational institutions, and public agencies in planning for recruitment, employment, and training.

wINB's current efforts in this survey consist of identifying employers and educational institutions as possible participants in the joint WINB-AEC. survey. If your organization currently employs technicians and/or offers training programs for any type of technicians in nuclear or radiation-related occupations, or if you anticipate doing so within the next five years. we would greatly appreciate your filling out the attached postal card and fort. warding it to us at your earliest convenience. We would especially. like to know the key person in your organization with whom we. might correspond corcerning this project.

Organizations indicating a "yes" response ard supplying the requested information on the attached card will receive more detailed questionnaires directly from the USAEC. Respondents. to the $A E C$ survey will receive copies of the survey results.

Thank you for your cooperation. Please call us collect if you have any questions concerning this project.

Yours truly,
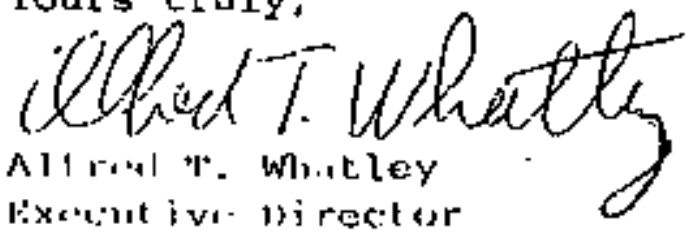

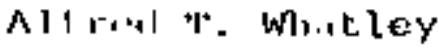

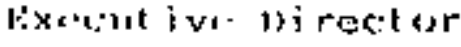

(This lettex mailed to 919 recipients: on september 6, 1973) 
Additionally, USAEC regional operations offices in Albuquerque, Idaho Falls, San Francisco, and Richland, washington were contacted to obtain, supplementary information as to key contacts and addresses of major federal contractors, laboratories, consultants, and other suppliers.

Development of key contact data consumed consider-". able time and effort and necessitated numerous telephone calls and exchanges of letters.

(4) Preparation of master list and mailing address labels

Upon completion of additional screening, crosschecking and other reviews, all source data selected for inclusion. in the population was categorized and coded to permit subsequent IBM keypunch and other data processing. The letter code* used is as follows:

$$
\begin{aligned}
& \mathbf{I}=\text { Industry } \\
& \mathbf{M}=\text { Medical, dental, and veterinarian } \\
& \mathbf{E}=\text { Educational } \\
& \mathbf{G}=\text { State, local, and federal government } \\
& \mathbf{C}=\text { AEc contractor }
\end{aligned}
$$

The above categories were designed to facilitate processing of the mailing labels and envelopes, and to aid in sorting the separate demand and supply questionnaires to be sent to the population.

IBM cards were punched for each entry; and these were processed by. (1) cátegory and (2) by zip code, to permit expeditious handling auring the mailing process. A master IBM print-out and several duplicate sets of address labels were prepared. Address labels were printed on IBM format and were of the "peel off" type permitting easy transfer from the lists directly to the mailing envelopes.

* USAEC is understood to be using 15 symbol codes in its categorization for a more detailed breakdown. 
One master 1 ist and three (3) sets of address labels were furnished to USAEC. A total of 3,009 entries were included in the lists. Table B pro$v i d e s$ a breakdown of the survey population on a state-by-state basis. 
Table B

SURVEY POPULATION BY STATE

AND CATEGORY

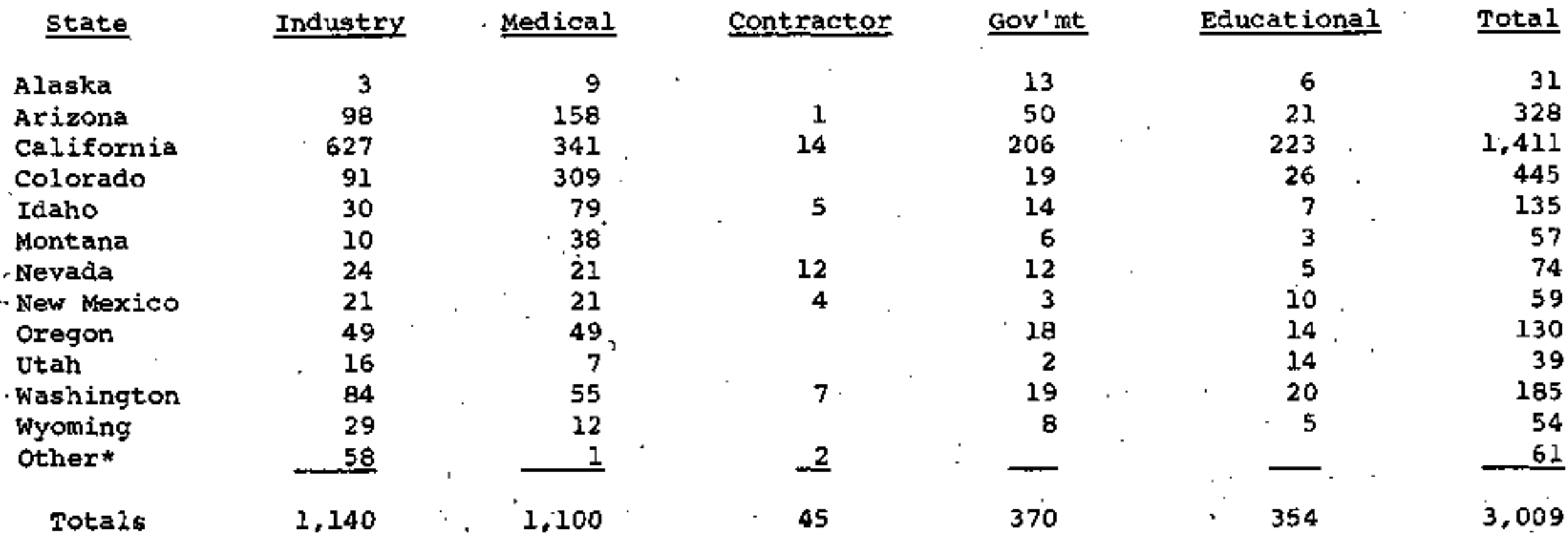

* Organizations having operations or factlities in the Western Region, bat which, identified their principal addresses outside the West. 
(5) Chronology

(a) Receipt of notice of contract award -April 23, 1973.

(b) Receipt of contract -- June 26, 1973

(c) Planning and project organization -i June 30 thru early July, 1973.

(d) Conpletion of preliminary data collection -September 1, 1973.

(e) Project review meetings -- August i6-17, 1973; october 26," 1973 .

(E) Questionnaires sent to 919 recipients -September 6, 1973.

(g) Follow-up information collection completed -November S, 1973.

(h) Preparation of final lists, address labels -November 5 thru Decenber 7, 1973.

(i) Submission of final lists, etc, to USAEC -December 10, 1973 . 


\section{BIBLIOGRAPHY}

1. Scientiflc and 'Pechnical Manpower Requirements of Selected Segments of the Atomic Energy Field, American Nuclear society and U. S. Atomic Energy Commission, 1970.

2. Guide to Scientific Instruments, American Association for the Advancement of Science, 1971-72.

3. Nuclear News Buyers Guide, 1973, American Nuclear society.

4. Nuclear Technician Manpower Survey: Approach to an Information System, Southern Interstate Nuclear Board. 1971.

5. Utility staffing and Training for Nuclear Power, U. S. Atomic Energy Cominission, 1973.

6. Radiation Protection Enroljment and Degxee Survey; U. S. Atomic Energy Commission, 1972.

7. Nuclear Engineering Enrollment and Degree Survey, U. S. Atomic Energy Comulssion; 1972.

8. Nuclear Radiation Technologist Manpower Survev: Northeastern Illinois Area. Illinois vocational and Technical Education Division.

Technician Yearbook, 1971-72, Prakken Publications, Inc.

Companies Holding Certificates of Authorization for Use of code Symbol Stamps, 1971, 1972, American Society of Mechanical Engineers.

11. Employment Characteristick of Atomic Energy Work, 1967, Bureau of Labor statistics, U. S. Department of Labor.

i2. Education Directory, Higher Education, 1972-73, National Center for Educational sțatistics. 
UNITED STATES

ATOMIC ENERGY COMMISSION

CHICAGO OPERATIONS OFFICE

9600 SOUTH CASS AVUNuR

AngONAE, JLLINOIS 60435

TELEOHONE

Apr11 10, 1974

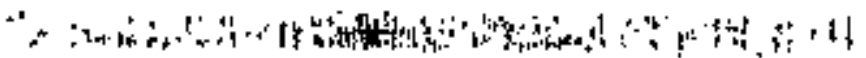

,

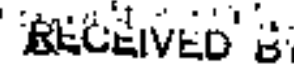

Arthur A, Churn, Derector

Patent Diviaton

FINAL RAPORT, CONTRAGT HO; AT(11-1)-2330, WESTERN INTERSTATE NUCLRAR BOARD

Enclosed is one copy of the finel report for this contract.

I would appreclate recelving your refommendations regarding clobe-out of thie contract insofar as the petant clearance la concerned.

Technical Approval has been recelved from Headquartere.

Hatahall Joagph

Sentor Contract Adninietrator

010:64

Contract: Hanageante Office

Enclosures:

1. FInnl Report No, C00-2330-1

2. Heno, Herrick to Hiller, April 2, 1974

ce: Technical Infoknation Center, Oak Ridge, Tenn, (TFRU GH RATBNT

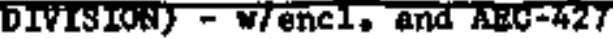

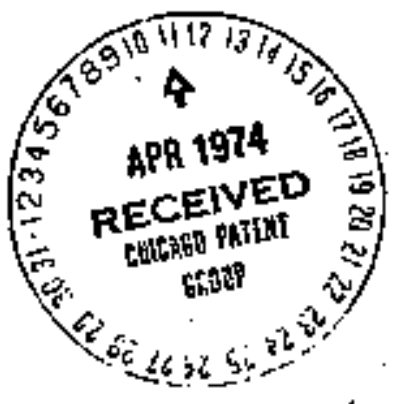

I RELLW - . . . . 